Review

\title{
Preparation and characterization of bulk $\mathrm{Mo}_{\mathrm{X}} \mathrm{C}$ catalysts and their use in the reverse water-gas shift reaction
}

\author{
Xianyun Liu ${ }^{\mathrm{a}, \mathrm{b}}$, Arturo Pajares ${ }^{\mathrm{a}, \mathrm{b}}$, DJ Donn Calinao Matienzo ${ }^{\mathrm{a}}$, Pilar Ramírez de la Piscina ${ }^{\mathrm{a}}$, \\ Narcís Homs ${ }^{\mathrm{a}, \mathrm{b}, *}$ \\ a Departament de Química Inorgànica i Orgànica, Secció de Química Inorgànica \& Institut de Nanociència i Nanotecnologia (IN2UB), Universitat de Barcelona, Martí i \\ Franquès 1, 08028, Barcelona, Spain \\ ${ }^{\mathrm{b}}$ Catalonia Institute for Energy Research (IREC), Jardins de les Dones de Negre 1, 08930, Barcelona, Spain
}

\section{A R T I C L E I N F O}

\section{Keywords:}

$\mathrm{CO}_{2}$

$\mathrm{CO}$

RWGS

Molybdenum carbides

Sol-gel method

\begin{abstract}
A B S T R A C T
In this work, different routes for the preparation of molybdenum carbides through sol-gel methods were studied; several parameters such as molybdenum precursor, carbon source and $\mathrm{Mo} / \mathrm{C}$ ratios were explored. The materials were characterized using different techniques, such as adsorption/desorption of $\mathrm{N}_{2}, \mathrm{XRD}$, Raman spectroscopy, SEM-EDX, TEM-EELS, $\mathrm{H}_{2}$-TPR and XPS. Depending on the preparation method used, the presence of different $\mathrm{Mo}_{\mathrm{x}} \mathrm{C}$ crystalline phases, $\mathrm{Mo}_{2} \mathrm{C}$ and/or MoC cubic and/or hexagonal, were determined. The catalytic behaviour in $\mathrm{CO}_{2}$ conversion for $\mathrm{CO}$ production through the reverse water gas shift reaction was tested using a reactant mixture $\mathrm{CO}_{2} / \mathrm{H}_{2}=1 / 3$ (molar ratio) at $0.1 \mathrm{MPa}$ and a gas hourly space velocity of $3000 \mathrm{~h}^{-1}$. Values of $\mathrm{CO}_{2}$ conversion up to $26 \%$, with nearly $100 \%$ selectivity to CO were achieved as a function of the reaction temperature and the catalyst used.
\end{abstract}

\section{Introduction}

In the last years many efforts have been applied for the capture and separation of $\mathrm{CO}_{2}$ from different effluents, because it is one of the main emissions contributing to the greenhouse effect. Nowadays $\mathrm{CO}_{2}$ is considered an alternative $\mathrm{C} 1$ feedstock that can be recycled and reused in different processes [1-3]. One of the processes that is recognized useful for the $\mathrm{CO}_{2}$ utilization is the reverse water gas shift (RWGS) reaction:

$\mathrm{CO}_{2}+\mathrm{H}_{2} \leftrightarrow \mathrm{CO}+\mathrm{H}_{2} \mathrm{O} \Delta \mathrm{H}^{\mathrm{o}}=41.2 \mathrm{~kJ} \cdot \mathrm{mol}^{-1}$

However, under RWGS conditions $\mathrm{CH}_{4}$ can be also produced from $\mathrm{CO}$ or $\mathrm{CO}_{2}$ hydrogenation:

$$
\begin{aligned}
& \mathrm{CO}+3 \mathrm{H}_{2} \leftrightarrow \mathrm{CH}_{4}+\mathrm{H}_{2} \mathrm{O} \Delta \mathrm{H}^{\mathrm{o}}=-206.1 \mathrm{~kJ} \cdot \mathrm{mol}^{-1} \\
& \mathrm{CO}_{2}+4 \mathrm{H}_{2} \leftrightarrow \mathrm{CH}_{4}+2 \mathrm{H}_{2} \mathrm{O} \Delta \mathrm{H}^{\mathrm{o}}=-164.9 \mathrm{~kJ} \cdot \mathrm{mol}^{-1}
\end{aligned}
$$

Depending on the catalyst and the reaction conditions used, reactions (2) and (3) contribute to a decrease in the selectivity to $\mathrm{CO}$ of the RWGS process.

Using an appropriate catalyst, after water separation, mixtures of synthesis gas $\left(\mathrm{CO}_{2} / \mathrm{CO} / \mathrm{H}_{2}\right)$ can be obtained. These mixtures can be used as feedstock in different industrial processes such as methanol production and Fischer-Tropsch synthesis.

Several metals have been used as active phases for the RWGS reaction, being Cu-, Ni- and noble metals-based catalysts the most studied [4-10]. One of the main problems of the use of Cu-based catalysts for the RWGS is their stability due to the sintering of the $\mathrm{Cu}$ active phase during the catalytic reaction [4,5]. On the other hand, Ni-based catalysts favour the methanation reaction [6] and the high cost of noble metals is an important drawback for their large scale utilization.

The similar properties of transition metal carbides (TMCs) to noble metals have led to their study as catalysts in different reactions [11,12]. In particular, TMCs are considered potential materials useful for the $\mathrm{CO}_{2}$ activation [13,14]. The activation of $\mathrm{CO}_{2}$ and $\mathrm{H}_{2}$ over different model TMCs-based catalysts has been theoretically studied [15-17]. Although the most studied TMCs in $\mathrm{CO}_{2}$ reduction have been molybdenum carbides, experimental studies have been mainly carried out using single crystal surfaces and/or at pressure higher than atmospheric [17].

Different routes have been used for the preparation of molybdenum carbides. The temperature-programed carburization of molybdenum or molybdenum oxides, usually $\mathrm{MoO}_{3}$, using hydrocarbon $/ \mathrm{H}_{2}$ mixtures as well as carbothermal reduction procedures have been widely applied;

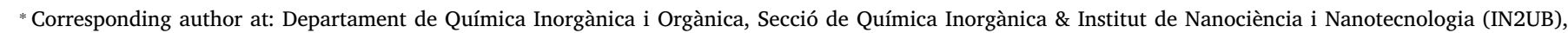
Universitat de Barcelona, Martí i Franquès 1, 08028, Barcelona, Spain.

E-mail address: narcis.homs@qi.ub.edu (N. Homs). 
these methods required careful thermal treatments at high temperatures [18-21]. Due to the increased interest in the synthesis of nanosized carbides, new routes based in solution chemistry have been proposed. These routes enable the use of different molybdenum and carbon precursors and an interaction of the starting materials at molecular level including "soft-chemistry" pathways can take place; usually lower treatment temperature and shorter time in the preparation are involved [22-26]. We have recently reported a polycrystalline hexagonal $\mathrm{Mo}_{2} \mathrm{C}$ highly effective in the RWGS under moderate conditions, which was prepared using a sol-gel method without carburization treatment [27]. Density functional theory (DFT) computational and experimental studies have shown that hexagonal $\mathrm{Mo}_{2} \mathrm{C}$ has a great capability in capturing and selectively decomposing $\mathrm{CO}_{2}$ into $\mathrm{CO}$ [27], the continuous $\mathrm{O}$ removal with $\mathrm{H}_{2}$ can lead to $\mathrm{H}_{2} \mathrm{O}$ formation during the RWGS. However, not all the surfaces of $\mathrm{Mo}_{2} \mathrm{C}$ bind adsorbates with an appropriate strength; some surfaces have been theoretically shown to bind adsorbates too strongly avoiding an easy release or removal and hindering the progress of the RWGS [27]. Thus, RWGS is sensitive to the exposed $\mathrm{Mo}_{2} \mathrm{C}$ surface. This background led us to study in the present work the RWGS over new $\mathrm{Mo}_{\mathrm{x}} \mathrm{C}$-based catalysts prepared via sol-gel methods using different molybdenum precursors and carbon sources. Catalysts were characterized using $\mathrm{N}_{2}$ adsorption/desorption isotherms, powder $\mathrm{X}$-ray diffraction (XRD), scanning and transmission electron microscopy (SEM, TEM), temperature programmed reduction with $\mathrm{H}_{2}\left(\mathrm{H}_{2}\right.$-TPR), $\mathrm{X}$ ray photoelectron spectroscopy (XPS) and Raman spectroscopy. The catalytic behaviour in the RWGS was analysed as a function of the characteristics of the catalysts which in turn depended on the preparation method used. Moreover, for the more performant catalyst, a long-time catalytic test, to verify its stability and catalytic behaviour, was carried out.

\section{Experimental}

\subsection{Preparation of catalysts}

Different $\mathrm{Mo}_{\mathrm{x}} \mathrm{C}$ catalysts were prepared using sol-gel methods and different Mo precursors and carbon sources. $\mathrm{MoCl}_{5}$ or $\left(\mathrm{NH}_{4}\right)_{6} \mathrm{Mo}_{7} \mathrm{O}_{24} \cdot 4 \mathrm{H}_{2} \mathrm{O}$ were used as Mo precursor; three different sources of carbon were used: urea, a mixture of citric acid and urea in the presence of ethylene glycol (EG), a mixture of ethylenediaminetetraacetic acid (EDTA) and ethylenediamine (ED), sucrose, and, 4,5-dicyanoimidazole (DI). In all cases, the Mo precursor was mixed with the carbon source in water or ethanol to form a viscous solution. The viscous solution was then treated at $333 \mathrm{~K}$ for $48 \mathrm{~h}$ in an oven under air to form a gel. After this, the sample was transferred into a tubular quartz reactor, treated under Ar flow $\left(20 \mathrm{~mL} \mathrm{~min}^{-1}\right)$ at $2 \mathrm{~K} \mathrm{~min}^{-1}$ up to $423 \mathrm{~K}$ and maintained $3 \mathrm{~h}$. Subsequently, the temperature was increased at $3 \mathrm{~K}$ $\mathrm{min}^{-1}$ up to $1073 \mathrm{~K}$ and kept $3 \mathrm{~h}$. Finally, the reactor was cooled down to room temperature under Ar flow and the catalyst was exposed to the ambient air without passivation. Table 1 shows metal precursor, carbon source and the carbon source/metal precursor ratio used for the preparation of catalysts labelled: $\mathrm{Mo}_{\mathrm{x}} \mathrm{C}-\mathrm{A}$ [27], $\mathrm{Mo}_{\mathrm{x}} \mathrm{C}-\mathrm{B}, \mathrm{Mo}_{\mathrm{x}} \mathrm{C}-\mathrm{C}, \mathrm{Mo}_{\mathrm{x}} \mathrm{C}-\mathrm{D}$, $\mathrm{Mo}_{\mathrm{x}} \mathrm{C}$-D1 and $\mathrm{Mo}_{\mathrm{x}} \mathrm{C}$-E. Additional experimental details for the preparation of the catalysts are given in the Supporting Information.

\subsection{Characterization of catalysts}

$\mathrm{N}_{2}$ adsorption-desorption isotherms were recorded at $77 \mathrm{~K}$ using a Micromeritics Tristar II 3020 equipment. Prior to the measurements, the samples were outgassed at $523 \mathrm{~K}$. The surface area $\left(\mathrm{S}_{\mathrm{BET}}\right)$ was calculated by multi-point B.E.T. analysis of nitrogen adsorption isotherms. XRD patterns were obtained with a PANalytical X'Pert PRO MPD Alpha1 powder diffractometer equipped with a $\mathrm{CuK \alpha} \alpha_{1}$ radiation. The XRD profiles were collected between $2 \theta=4^{\circ}$ and $2 \theta=100^{\circ}$, with a step width of $0.017^{\circ}$ and by counting $50 \mathrm{~s}$ at each step.

Raman spectroscopy analyses were registered using a Jobin-Yvon LabRam HR 800, fitted to an optical Olympus BXFM microscope with a $532 \mathrm{~nm}$ laser and a CCD detector. The Raman spectra of the samples were collected with laser power limited to $1.5 \mathrm{~mW}$ to minimize laserheating effects. $\mathrm{H}_{2}$-TPR experiments were performed using a Micromeritics AutoChem II 2920 chemisorption analyser. Approximately $50 \mathrm{mg}$ of sample was pretreated at $363 \mathrm{~K}$ under flowing He. After cooling to room temperature, the sample was exposed to a $\mathrm{H}_{2} /$ $\operatorname{Ar}(12 \% \mathrm{v} / \mathrm{v})$ flow, and the temperature was linearly increased at $10 \mathrm{~K}$ $\min ^{-1}$ up to $1073 \mathrm{~K}$.

SEM analysis was carried out in a JEOL $J$-7100 F microscope working with an electron acceleration potential of $20 \mathrm{kV}$ and equipped with an energy dispersive X-ray (EDX) detector. The EDX analysis was performed with an Oxford Instrument INCA at an acquisition time of $60 \mathrm{~s}$. TEM images and electron energy loss (EEL) spectra were acquired in a JEOL $2010 \mathrm{~F}$ microscope, equipped with a field emission electron gun working with an electron acceleration potential of $200 \mathrm{kV}$ and coupled to a Gatan imaging filter.

The XPS were obtained in a PerkinElmer PHI-5500 Multitechnique System equipment with an Al X-ray source (ho $=1486.6 \mathrm{eV}$ and $350 \mathrm{~W}$ ). All measurements were carried out in an ultrahigh vacuum chamber ( $\mathrm{P}<2 \times 10^{-8}$ Torr). The binding energy (BE) values were referred to the $\mathrm{C} 1 \mathrm{~s} \mathrm{BE}$ of adventitious carbon at $284.8 \mathrm{eV}$, which was previously determined in the same equipment and conditions, using $\mathrm{Au}$ as reference.

\subsection{Catalytic tests}

The RWGS reaction tests were carried out using a tubular fixed-bed reactor (316-L stainless steel, $305 \mathrm{~mm}$ long, $9 \mathrm{~mm}$ i.d.) provided with a thermocouple in direct contact with the catalyst in a MicroactivityReference unit (PID Eng\&Tech). The catalyst sample, approximately $150 \mathrm{mg}$, was diluted with silicon carbide up to $1 \mathrm{~mL}$. Catalyst was firstly

Table 1

Several parameters of $\mathrm{Mo}_{\mathrm{x}} \mathrm{C}$ preparation and $\mathrm{S}_{\mathrm{BET}}$ values and crystallite size (determined by XRD) of Mo $\mathrm{C}$.

\begin{tabular}{|c|c|c|c|c|c|c|}
\hline \multirow[t]{2}{*}{ Catalyst } & \multirow[t]{2}{*}{ Metal precursor } & \multirow[t]{2}{*}{ Carbon source } & \multirow[t]{2}{*}{ mol Carbon source/mol Metal precursor } & \multicolumn{2}{|c|}{$\mathrm{S}_{\mathrm{BET}}\left(\mathrm{m}^{2} \mathrm{~g}^{-1}\right)$} & \multirow[t]{2}{*}{ Crystallite size (nm) } \\
\hline & & & & Fresh & Used & \\
\hline $\mathrm{Mo}_{\mathrm{x}} \mathrm{C}-\mathrm{A}$ & $\mathrm{MoCl}_{5}$ & urea & 7 & 8 & 5 & 35.2 \\
\hline $\mathrm{Mo}_{\mathrm{x}} \mathrm{C}-\mathrm{B}$ & $\left(\mathrm{NH}_{4}\right)_{6} \mathrm{Mo}_{7} \mathrm{O}_{24} \cdot 4 \mathrm{H}_{2} \mathrm{O}$ & urea $+\mathrm{EG}^{1}+\mathrm{CA}^{2}$ & urea,7; EG,7; CA,7 & 15 & 11 & 12.2 \\
\hline $\mathrm{Mo}_{\mathrm{x}} \mathrm{C}-\mathrm{C}$ & $\left(\mathrm{NH}_{4}\right)_{6} \mathrm{Mo}_{7} \mathrm{O}_{24} \cdot 4 \mathrm{H}_{2} \mathrm{O}$ & $\mathrm{EDTA}^{3}+\mathrm{ED}^{4}$ & EDTA, 3.5; ED,7 & 9 & - & 4.6 \\
\hline $\mathrm{Mo}_{\mathrm{x}} \mathrm{C}-\mathrm{D}$ & $\left(\mathrm{NH}_{4}\right)_{6} \mathrm{Mo}_{7} \mathrm{O}_{24} \cdot 4 \mathrm{H}_{2} \mathrm{O}$ & sucrose & 12 & $<5$ & $<5$ & 3.3 \\
\hline $\mathrm{Mo}_{\mathrm{x}} \mathrm{C}-\mathrm{D} 1$ & $\left(\mathrm{NH}_{4}\right)_{6} \mathrm{Mo}_{7} \mathrm{O}_{24} \cdot 4 \mathrm{H}_{2} \mathrm{O}$ & sucrose & 6.6 & $<5$ & $<5$ & 20.6 \\
\hline $\mathrm{Mo}_{\mathrm{x}} \mathrm{C}-\mathrm{E}$ & $\mathrm{MoCl}_{5}$ & ${ }^{5} \mathrm{DI}$ & 0.5 & 18 & 28 & 25.0 \\
\hline
\end{tabular}

1 EG: Ethylene glycol.

2 CA: Citric acid.

3 EDTA: Ethylenediaminetetraacetic acid.

4 ED: Ethylenediamine.

5 DI: 4,5-dicyanoimidazole. 
treated under $\mathrm{N}_{2}$ flow from $298 \mathrm{~K}$ up to $598 \mathrm{~K}$ for $3 \mathrm{~h}$. Then, the reactant $\mathrm{CO}_{2} / \mathrm{H}_{2} / \mathrm{N}_{2}=1 / 3 / 1$ mixture, under a gas hourly space velocity (GHSV) of $3000 \mathrm{~h}^{-1}$, was introduced. The RWGS was studied at $0.1 \mathrm{MPa}$, between $548 \mathrm{~K}$ and $673 \mathrm{~K}$, following the temperature sequence: $598 \mathrm{~K}$ $(3 \mathrm{~h}) \rightarrow 573 \mathrm{~K}(3 \mathrm{~h}) \rightarrow 548 \mathrm{~K}(10 \mathrm{~h}) \rightarrow 598 \mathrm{~K}(3 \mathrm{~h}) \rightarrow 623 \mathrm{~K}(3 \mathrm{~h}) \rightarrow 648 \mathrm{~K}$ $(3 \mathrm{~h}) \rightarrow 673 \mathrm{~K}(3 \mathrm{~h}) \rightarrow 648 \mathrm{~K}(5 \mathrm{~h})$. An additional long-term catalytic test of about $100 \mathrm{~h}$ on stream at $623 \mathrm{~K}$, was carried out over the $\mathrm{Mo}_{\mathrm{x}} \mathrm{C}-\mathrm{B}$, which was the most performant catalyst. The reactor effluent was analysed on-line with a Varian 450-GC equipped with a methanizer, a TCD and two FID detectors. The system was allowed to stabilize at each temperature at least for $1 \mathrm{~h}$ before the analysis, which was performed twice. The corresponding blank tests with the empty reactor and with $\mathrm{SiC}$ showed a negligible contribution to the reaction under the experimental conditions used.

\section{Results and discussion}

As stated before, catalysts prepared in this work are shown in Table 1; the preparation and characterization of $\mathrm{Mo}_{\mathrm{X}} \mathrm{C}-\mathrm{A}$ has been recently reported [27]. All catalysts have low values of BET surface-area (Table 1), being the highest that of MoxC-E $\left(18 \mathrm{~m}^{2} \mathrm{~g}^{-1}\right)$. XRD diffraction patterns (Fig. 1) indicate the presence of different $\mathrm{Mo}_{\mathrm{X}} \mathrm{C}$ phases with different crystallinity degree as a function of the preparation method used. XRD patterns of $\mathrm{Mo}_{\mathrm{X}} \mathrm{C}-\mathrm{A}, \mathrm{Mo}_{\mathrm{X}} \mathrm{C}-\mathrm{D} 1$ and $\mathrm{Mo}_{\mathrm{X}} \mathrm{C}-\mathrm{E}$ clearly show peaks corresponding to hexagonal $\mathrm{Mo}_{2} \mathrm{C}$ (JCPDS 00-035-0787) with high crystallinity. In all the other catalysts, the presence of hexagonal $\mathrm{Mo}_{2} \mathrm{C}$ with lower crystallinity can be proposed. On the other hand, the presence of a wide peak at $2 \theta=36-39^{\circ}$ and the absence of a peak at $2 \theta=48.8^{\circ}$ could be related with the presence of cubic $\mathrm{Mo}_{2} \mathrm{C}$ (JCPDS 00-015-0457) and/or MoC (JCPDS 03-065-0280) in Mo ${ }_{x} \mathrm{C}-\mathrm{B}, \mathrm{Mo}_{\mathrm{x}} \mathrm{C}-\mathrm{C}$,

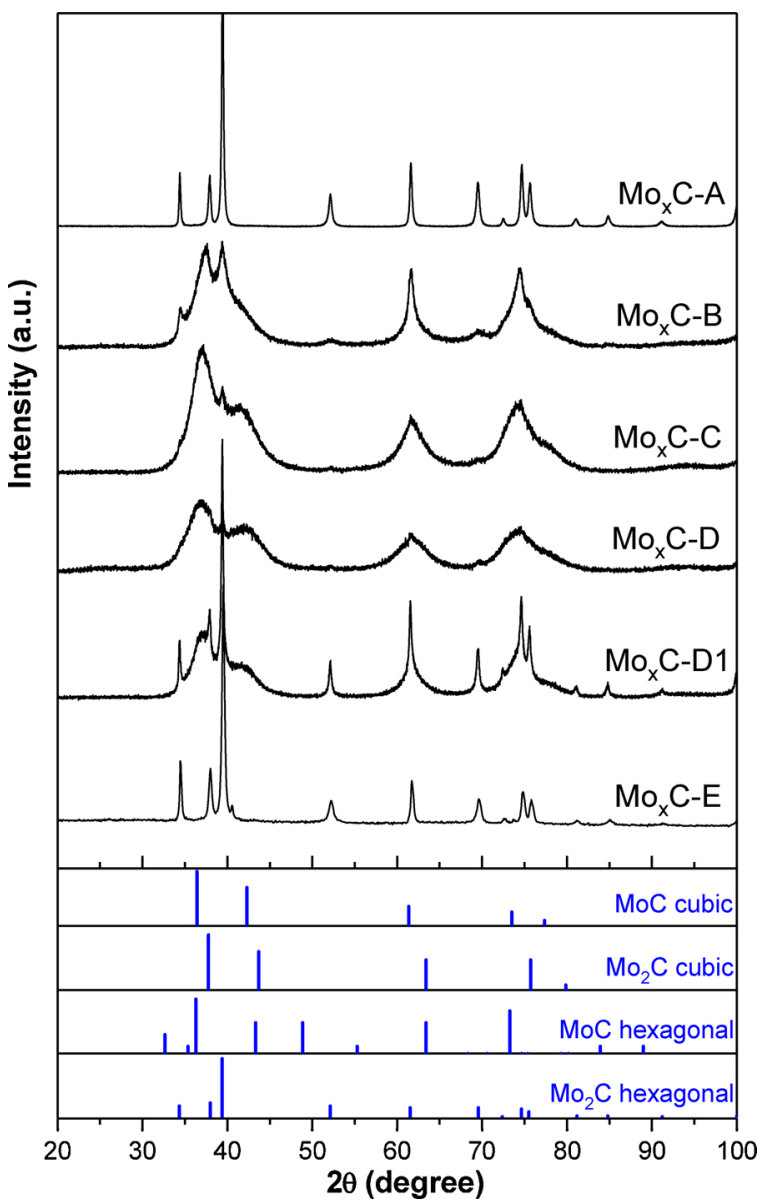

Fig. 1. XRD patterns of $\mathrm{Mo}_{\mathrm{x}} \mathrm{C}$ catalysts prepared using different methods.

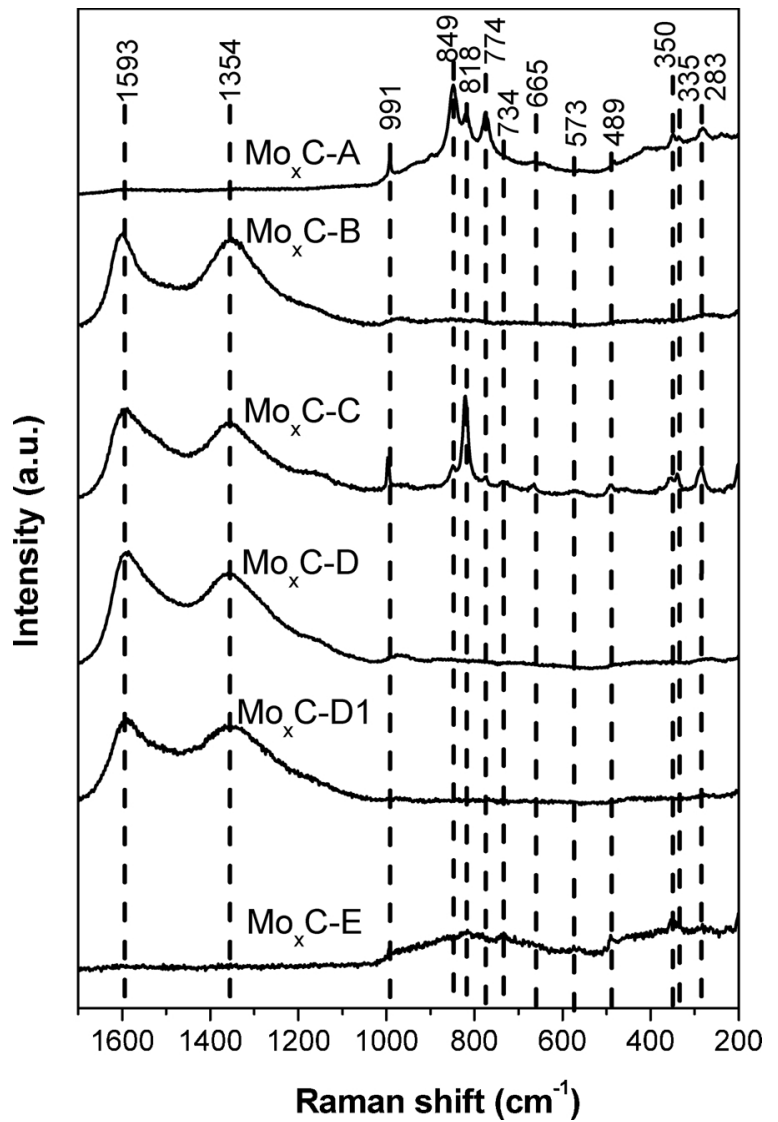

Fig. 2. Raman spectra of $\mathrm{Mo}_{\mathrm{x}} \mathrm{C}$ catalysts prepared using different methods.

$\mathrm{Mo}_{\mathrm{X}} \mathrm{C}-\mathrm{D}$ and $\mathrm{Mo}_{\mathrm{X}} \mathrm{C}-\mathrm{D} 1$. Moreover, in the pattern of $\mathrm{Mo}_{\mathrm{X}} \mathrm{C}-\mathrm{E}$, peaks with very low intensity, the most intense at $40.5^{\circ}$, characteristics of $\mathrm{Mo}^{0}$ (JCPDS 00-042-1120) were found (Fig. 1). From XRD patterns, the presence of crystalline oxycarbide species $\left(\mathrm{Mo}_{\mathrm{x}} \mathrm{O}_{\mathrm{y}} \mathrm{C}_{\mathrm{z}}\right)$ cannot be ruled out, because only a very small shift on the peak positions of pure $\mathrm{Mo}_{\mathrm{x}} \mathrm{C}$ phases would be expected when oxycarbide is formed, being the shift a function of the amount of $\mathrm{O}$ in the oxycarbide [28,29]. Using the Scherrer equation and the diffraction peak at about $2 \theta=61.6^{\circ}$, the crystallite sizes of $\mathrm{Mo}_{\mathrm{X}} \mathrm{C}$ were calculated, which range from $3.3 \mathrm{~nm}$ (Mox $\mathrm{C}-\mathrm{D})$ to $35.2 \mathrm{~nm}\left(\mathrm{Mo}_{\mathrm{X}} \mathrm{C}-\mathrm{A}\right)$ (Table 1 ).

Raman spectra were recorded in different zones to determine the presence of molybdenum oxides and/or residual carbon in the catalysts. Except for $\mathrm{Mo}_{\mathrm{x}} \mathrm{C}-\mathrm{A}$ and $\mathrm{Mo}_{\mathrm{x}} \mathrm{C}-\mathrm{E}$, the presence of two bands at about 1350 and $1580 \mathrm{~cm}^{-1}$ (D and $\mathrm{G}$ bands) indicate the presence of carbonaceous residues in the catalysts (Fig. 2). The bands in the zone $200-1000 \mathrm{~cm}^{-1}$ point to the presence of different surface molybdenum oxide species, mainly $\mathrm{MoO}_{3}$, with characteristic Raman bands at about 991, 849, 818, 774, 665, 350, 335 and $283 \mathrm{~cm}^{-1}$; the small intensity bands at about 734,573 and $489 \mathrm{~cm}^{-1}$ are related to the presence of $\mathrm{MoO}_{3-\mathrm{x}}$ intermediate oxides [30-35]. The intensity of the bands in the $200-1000 \mathrm{~cm}^{-1}$ zone is lower for the Raman spectra corresponding to $\mathrm{Mo}_{\mathrm{X}} \mathrm{C}-\mathrm{B}, \mathrm{Mo}_{\mathrm{X}} \mathrm{C}-\mathrm{D}$ and $\mathrm{Mo}_{\mathrm{X}} \mathrm{C}-\mathrm{D} 1$, indicating the presence of less amount of oxide species on the surface of these catalysts. These species could be formed when $\mathrm{Mo}_{\mathrm{x}} \mathrm{C}$ catalysts were exposed to air after the preparation $[27,36]$. A different surface reactivity of the catalysts towards oxygen and mild oxidants is suggested.

MoxC-B, which was the most performant catalyst in the RWGS (vide infra), was deeper characterized using SEM-EDX and HRTEM-EELS techniques. Fig. 3A shows the SEM image and the corresponding EDX analysis, which indicates the major presence of Mo and C in the sample and a small amount of O; EDX signals corresponding to N-containing species were not found (see inset in Fig. 3A). A rather wide particle size 

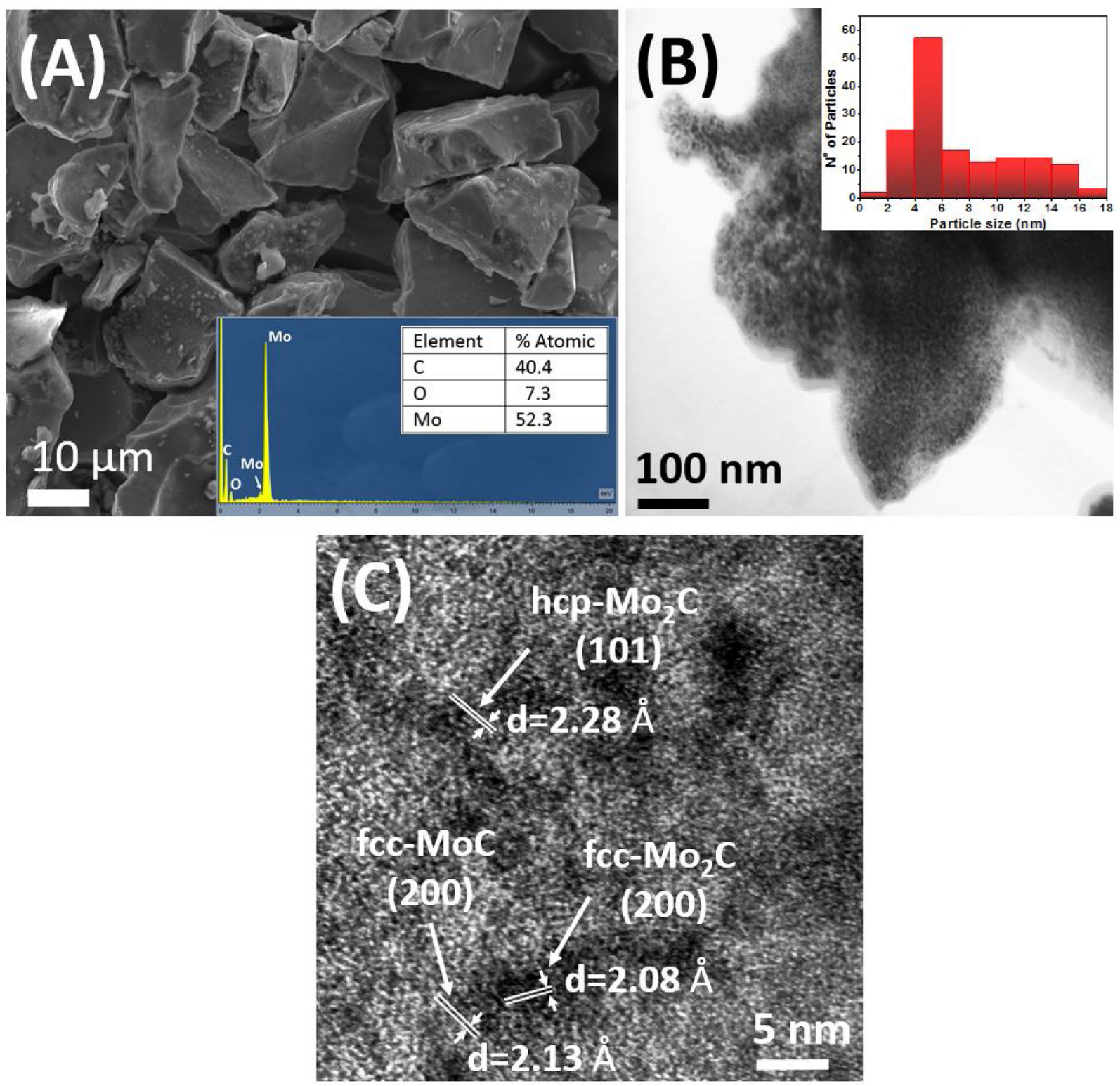

Fig. 3. SEM-EDX and TEM analysis of $\mathrm{Mo}_{\mathrm{x}} \mathrm{C}-\mathrm{B}$. (A) SEM image and EDX spectrum (inset); (B) TEM image and particle size distribution (inset); (C) HRTEM image.

distribution $(2-16 \mathrm{~nm})$ is determined from TEM analysis (inset in Fig. 3B). An HRTEM analysis (Fig. 3C), allowed the identification of nanosized particles of hcp $\mathrm{Mo}_{2} \mathrm{C}$, fcc $\mathrm{Mo}_{2} \mathrm{C}$ and fcc $\mathrm{MoC}$ phases in this catalyst. Finally the electron energy loss spectroscopy analysis (Fig. S1), confirmed the presence of Mo, C and $\mathrm{O}$ in the samples according to EDX results.

Fig. 4 shows the $\mathrm{H}_{2}$-TPR profiles. All catalysts, showed $\mathrm{H}_{2}$-compsumption peaks below $600 \mathrm{~K}$ that can be related with the reduction of $\mathrm{Mo}_{\mathrm{x}} \mathrm{C}_{\mathrm{y}} \mathrm{O}_{\mathrm{z}}$ oxycarbide species that could be formed when catalysts were exposed to air after preparation $[27,37] . \mathrm{H}_{2}$-TPR peaks in the $600-800 \mathrm{~K}$ zone could be related with the reduction of $\mathrm{Mo}^{5+}$ and/or $\mathrm{Mo}^{6+}$ in molybdenum oxides. Although peaks over $800 \mathrm{~K}$ could be related with the reduction of $\mathrm{MoO}_{2}$ on the surface of catalysts $[27,38]$, the formation of $\mathrm{CH}_{4}$ from the residual carbon, which will contribute to the TCD signal cannot be discarded.

$\mathrm{C} 1 \mathrm{~s}$, Mo $3 \mathrm{~d}$ and $\mathrm{O} 1 \mathrm{~s}$ core levels of $\mathrm{Mo}_{\mathrm{x}} \mathrm{C}$ catalysts were analyzed by XPS. When $\mathrm{MoCl}_{5}$ was used in the preparation of catalysts $\left(\mathrm{Mo}_{\mathrm{X}} \mathrm{C}-\mathrm{A}\right.$ and $\left.\mathrm{Mo}_{\mathrm{X}} \mathrm{C}-\mathrm{E}\right), \mathrm{Cl} 2 \mathrm{p}$ level was also analysed; the absence of $\mathrm{Cl} 2 \mathrm{p}$ signals

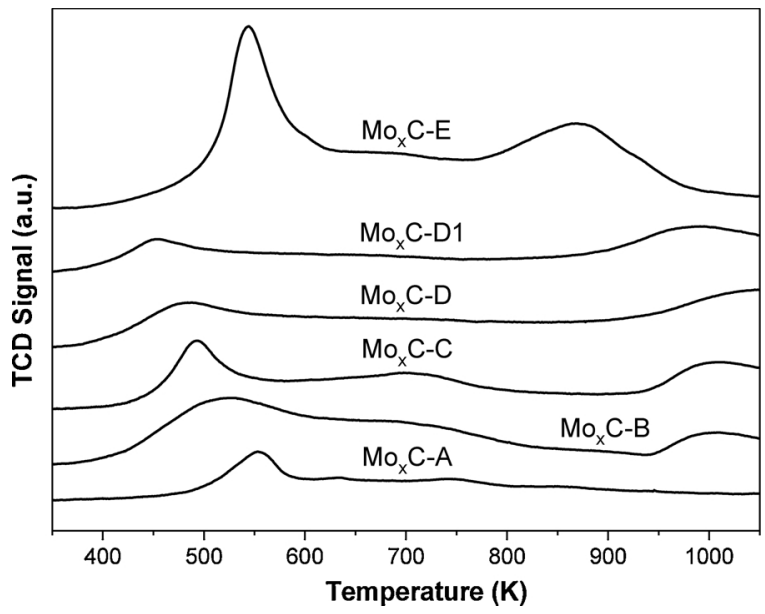

Fig. 4. $\mathrm{H}_{2}$-TPR profiles of $\mathrm{Mo}_{\mathrm{x}} \mathrm{C}$ catalysts prepared using different methods. 
indicated the absence of residual $\mathrm{Cl}$ on the surface of Mox $\mathrm{C}-\mathrm{A}$ and Mox C-E. Fig. S2 shows the $\mathrm{C} 1 \mathrm{~s}$ and Mo $3 \mathrm{~d}$ spectra of $\mathrm{Mo}_{\mathrm{x}} \mathrm{C}$ catalysts. In all cases, C 1s spectra show an intense and asymmetric peak with maximum at $284.8 \mathrm{eV}$, which can be deconvoluted into four components at $283.4-283.8 \mathrm{eV}, 284.8 \mathrm{eV}$ (adventitious carbon), 285.7-286.2 eV and 288.7-289.2 eV (Fig. S2). The component at the lowest BE (283.4-283.8) is related with the presence of Mo-C in molybdenum carbide and/or oxycarbide species, those at higher $\mathrm{BE}$ are related to $\mathrm{C}-\mathrm{O}$ and $\mathrm{O}=\mathrm{C}-\mathrm{O}$, respectively $[39,43]$. Although the Mo $3 \mathrm{~d}$ spectra are complex (Fig. S2), they can be properly deconvoluted into four Mo $3 d_{5 / 2}$-Mo $3 d_{3 / 2}$ doublets with a ratio (intensity Mo $3 d_{5 / 2} /$ intensity Mo $3 \mathrm{~d}_{3 / 2}$ ) $=1.5$ and a Mo $3 \mathrm{~d}_{5 / 2}$-Mo $3 \mathrm{~d}_{3 / 2}$ splitting of $3.1 \mathrm{eV}$ [44]. Mo $3 \mathrm{~d}_{5 / 2}$ components at $233.0-233.4 \mathrm{eV}, 231.8-232.2 \mathrm{eV}$ and $229,6-230 \mathrm{eV}$ are assigned to $\mathrm{Mo}^{6+}, \mathrm{Mo}^{5+}$ and $\mathrm{Mo}^{4+}$ surface species, respectively and are related with the presence of surface oxide molybdenum species [42-44]. The peak at $228.7-228.9 \mathrm{eV}$ can be related to the presence of $\mathrm{Mo}_{\mathrm{x}} \mathrm{C}$ and/or oxycarbide species [39,43], for $\mathrm{Mo}_{\mathrm{x}} \mathrm{C}-\mathrm{E}$ sample, the intensity of this peak was very low indicating an easier oxidation of the surface species in this case. In all cases $\mathrm{O} 1 \mathrm{~s}$ profiles (not shown) showed a main broad and asymmetric peak centred at about $531.1 \mathrm{eV}$, which can be related to oxide anions in molybdenum oxide and/or oxycarbide species on the surface, shoulders at higher BE are associated to residual species containing $\mathrm{C}-\mathrm{O}$ and $\mathrm{C}=\mathrm{O}$ [39-41,43,45].

All catalysts prepared in this work were active and highly selective in the RWGS using a reactant mixture of $\mathrm{CO}_{2} / \mathrm{H}_{2}=1 / 3$ at $0.1 \mathrm{MPa}$ and $548-673 \mathrm{~K}$; catalytic results are shown in Table 2 . As expected, in all cases $\mathrm{CO}_{2}$ conversion and $\mathrm{CO}$ yield increased with the increase of temperature. The main product formed was $\mathrm{CO}$ and only small amounts of $\mathrm{CH}_{4}$, and in some cases negligible amounts of ethylene and propylene, were detected. The $\mathrm{CO}$ selectivity values were always higher than $91 \% ; \mathrm{Mo}_{\mathrm{x}} \mathrm{C}-\mathrm{B}, \mathrm{Mo}_{\mathrm{x}} \mathrm{C}-\mathrm{D} 1$ and $\mathrm{Mo}_{\mathrm{x}} \mathrm{C}-\mathrm{E}$ showed selectivity to $\mathrm{CO}$ always higher than $97 \%$ (Fig. 5). The highest $\mathrm{CO}$ production was obtained over $\mathrm{Mo}_{\mathrm{x}} \mathrm{C}-\mathrm{B}$ (Table 2); as stated above, in this catalyst the coexistence of hexagonal $\mathrm{Mo}_{2} \mathrm{C}$ and cubic $\mathrm{Mo}_{2} \mathrm{C}$ and $\mathrm{MoC}$ with poor crystallinity was found; the coexistence of different MoxC phases could result in an inbetween interface region with enhanced activity. For oxide-supported $\mathrm{Cu}$-based catalysts a main role of the interface region in the RWGS has been reported $[46,47]$. On the other hand, $\mathrm{Mo}_{\mathrm{x}} \mathrm{C}-\mathrm{A}$ and $\mathrm{Mo}_{\mathrm{x}} \mathrm{C}-\mathrm{E}$, with only highly crystalline hexagonal $\mathrm{Mo}_{2} \mathrm{C}$ as carbide phase, were the less performant catalysts under the reaction condition used.

The apparent activation energy $\left(\mathrm{E}_{\mathrm{a}}\right)$ for $\mathrm{CO}$ production calculated from Arrhenius plots (Fig. S3) in the 598-648 K range, are: $\mathrm{Mo}_{\mathrm{x}} \mathrm{C}-\mathrm{B}$ $\left(37.8 \pm 2.4 \mathrm{~kJ} \mathrm{~mol}^{-1}\right)<\mathrm{Mo}_{\mathrm{x}} \mathrm{C}-\mathrm{D}\left(42.4 \pm 1.6 \mathrm{~kJ} \mathrm{~mol}^{-1}\right)<\mathrm{Mo}_{\mathrm{x}} \mathrm{C}-\mathrm{D} 1$ $\left(45.2 \pm 2.3 \mathrm{~kJ} \mathrm{~mol}^{-1}\right)<\mathrm{Mo}_{\mathrm{x}} \mathrm{C}-\mathrm{E} \quad\left(47.8 \pm 0.5 \mathrm{~kJ} \mathrm{~mol}^{-1}\right)<\mathrm{Mo}_{\mathrm{x}} \mathrm{C}-\mathrm{C}$ $\left(53.7 \pm 3.3 \mathrm{~kJ} \mathrm{~mol}^{-1}\right)<\mathrm{Mo}_{\mathrm{x}} \mathrm{C}-\mathrm{A}\left(56.5 \pm 1.5 \mathrm{~kJ} \mathrm{~mol}^{-1}\right)$. These values compare well with those reported for different metallic- and oxidicbased catalysts for RWGS [48-51]. $\mathrm{Mo}_{\mathrm{x}} \mathrm{C}-\mathrm{A}$ catalyst in which only the presence of hcp- $\mathrm{Mo}_{2} \mathrm{C}$ could be identified [27], showed the highest $\mathrm{E}_{\mathrm{a}}$ value. It is noticeable the low $\mathrm{E}_{\mathrm{a}}$ value $\left(37.8 \pm 2.4 \mathrm{~kJ} \mathrm{~mol}^{-1}\right)$ determined for $\mathrm{Mo}_{\mathrm{x}} \mathrm{C}-\mathrm{B}$. $\mathrm{Mo}_{\mathrm{x}} \mathrm{C}$-B catalyst showed the best performance in

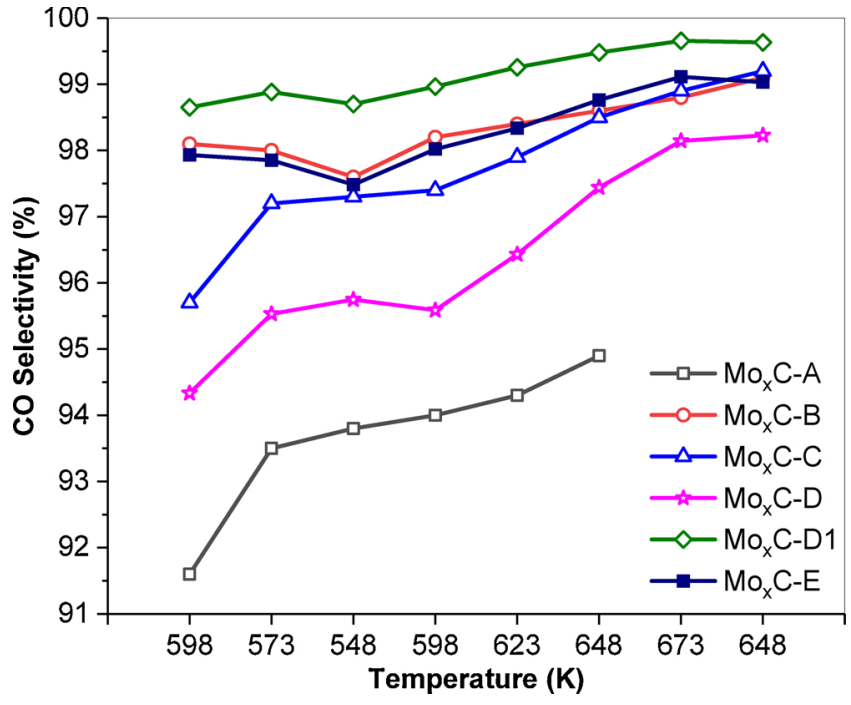

Fig. 5. CO selectivity variation with RWGS temperature for $\mathrm{Mo}_{\mathrm{x}} \mathrm{C}$ catalysts. Reaction conditions: $150 \mathrm{mg}$ catalyst, $\mathrm{CO}_{2} / \mathrm{H}_{2} / \mathrm{N}_{2}=1 / 3 / 1, \mathrm{GHSV}=3000 \mathrm{~h}^{-1}$, $\mathrm{P}=0.1 \mathrm{MPa}$.

RWGS under the experimental conditions used; an Ea of CO formation of $34 \mathrm{~kJ} \mathrm{~mol}^{-1}$ has been recently reported for high performant alkalipromoted Pt-based catalysts [50,51]. As discussed above, the ability of $\mathrm{CO}_{2}$ dissociation into $\mathrm{CO}$ and $\mathrm{O}$ intermediates and the strength of adsorption on $\mathrm{Mo}_{2} \mathrm{C}$ are key points in the RWGS reaction over $\mathrm{Mo}_{2} \mathrm{C}$, and these parameters depend on the exposed $\mathrm{Mo}_{2} \mathrm{C}$ surface [27]. One could propose the presence of more surface centres with appropriate characteristics for $\mathrm{CO}_{2}$ activation and appropriate ability removal of $\mathrm{CO}$ and $\mathrm{O}$ formed on $\mathrm{Mo}_{\mathrm{x}} \mathrm{C}-\mathrm{B}$ when compared with the other catalysts.

The sequence of temperature carried out in the catalytic test allowed to evaluate the catalytic behaviour at $598 \mathrm{~K}$ initially and after about $20 \mathrm{~h}$ of catalytic reaction. In all cases, the $\mathrm{CO}$ selectivity slightly increased after this time (Fig. 5). Moreover, the $\mathrm{CO}_{2}$ conversion and $\mathrm{CO}$ yield values obtained at $648 \mathrm{~K}$ after about $36 \mathrm{~h}$ of catalytic test, once the RWGS was studied at $673 \mathrm{~K}$, were very similar to those found at $648 \mathrm{~K}$ after about $27 \mathrm{~h}$ of reaction (Table 2); the highest decrease of $\mathrm{CO}_{2}$ conversion and $\mathrm{CO}$ yield $(\approx 5 \%)$ at $648 \mathrm{~K}$ after this sequence was observed for $\mathrm{Mo}_{\mathrm{x}} \mathrm{C}$-E. The more performant $\mathrm{Mo}_{\mathrm{x}} \mathrm{C}-\mathrm{B}$ catalyst was tested for about $100 \mathrm{~h}$ under the RWGS conditions used in order to verify the stability of its catalytic behaviour. Fig. 6 shows the $\mathrm{CO}_{2}$ conversion and selectivity to $\mathrm{CO}$ along time on stream at $623 \mathrm{~K}$. As can be seen the $\mathrm{CO}_{2}$ conversion was kept almost constant along the $96 \mathrm{~h}$ at about $18 \%$ under RWGS conditions, with a selectivity to CO near to $98 \%$.

Post-reaction catalysts were analysed by $\mathrm{S}_{\mathrm{BET}}$, XRD and Raman spectroscopy. In general, $S_{\mathrm{BET}}$ values of post-reaction catalysts were similar to those of fresh samples (Table 1). Except for $\mathrm{Mo}_{\mathrm{x}} \mathrm{C}-\mathrm{E}, \mathrm{XRD}$ patterns of post-reaction catalysts did not show significant differences

Table 2

$\mathrm{CO}$ yield and $\mathrm{CO}_{2}$ conversion over $\mathrm{Mo}_{\mathrm{x}} \mathrm{C}$ catalysts at different temperatures. RWGS reaction conditions: $150 \mathrm{mg}$ catalyst, $\mathrm{CO}_{2} / \mathrm{H}_{2} / \mathrm{N}_{2}=1 / 3 / 1, \mathrm{GHSV}=3000 \mathrm{~h}^{-1}$, $\mathrm{P}=0.1 \mathrm{MPa}$.

\begin{tabular}{|c|c|c|c|c|c|c|}
\hline \multirow[t]{2}{*}{$\mathrm{T} / \mathrm{K}$} & \multicolumn{6}{|c|}{$\mathrm{CO}$ yield $/ \mathrm{mol} \mathrm{CO} \mathrm{kg}$ cat $^{-1} \mathrm{~h}^{-1}\left(\% \mathrm{CO}_{2}\right.$ conversion $)$} \\
\hline & $\mathrm{Mo}_{\mathrm{x}} \mathrm{C}-\mathrm{A}$ & $\mathrm{Mo}_{\mathrm{x}} \mathrm{C}-\mathrm{B}$ & $\mathrm{Mo}_{\mathrm{x}} \mathrm{C}-\mathrm{C}$ & $\mathrm{Mo}_{\mathrm{x}} \mathrm{C}-\mathrm{D}$ & $\mathrm{Mo}_{\mathrm{x}} \mathrm{C}-\mathrm{D} 1$ & $\mathrm{Mo}_{\mathrm{x}} \mathrm{C}-\mathrm{E}$ \\
\hline 598 & $9.0(6.0)$ & $18.6(11.6)$ & $12.2(7.6)$ & $15.0(9.7)$ & $13.6(8.4)$ & $12.0(7.5)$ \\
\hline 573 & $5.6(3.6)$ & $11.4(7.1)$ & $6.9(4.3)$ & $10.1(6.5)$ & $8.3(5.1)$ & $6.6(4.1)$ \\
\hline 548 & $2.9(1.9)$ & $5.8(3.6)$ & 3.1 (1.9) & $5.3(3.4)$ & $4.0(2.5)$ & $3.2(2.0)$ \\
\hline 598 & $10.8(7.0)$ & $18.8(11.7)$ & 13.1 & $15.1(9.7)$ & $14.1(8.7)$ & $11.5(7.2)$ \\
\hline 623 & $17.4(11.3)$ & 26.4 (16.4) & $21.0(13.1)$ & $21.8(13.8)$ & 20.9 (12.9) & $17.7(11.0)$ \\
\hline 648 & 25.9 (16.7) & $33.8(21.0)$ & 29.8 (18.5) & $29.2(18.3)$ & $28.4(17.5)$ & 25.1 \\
\hline 673 & - & $41.8(25.9)$ & $38.2(23.7)$ & $36.7(22.8)$ & $36.2(22.2)$ & $33.0(20.3)$ \\
\hline 648 & -- & $33.6(20.7)$ & 29.1 (17.9) & $29.7(18.5)$ & $28.6(17.5)$ & $23.8(14.7)$ \\
\hline
\end{tabular}




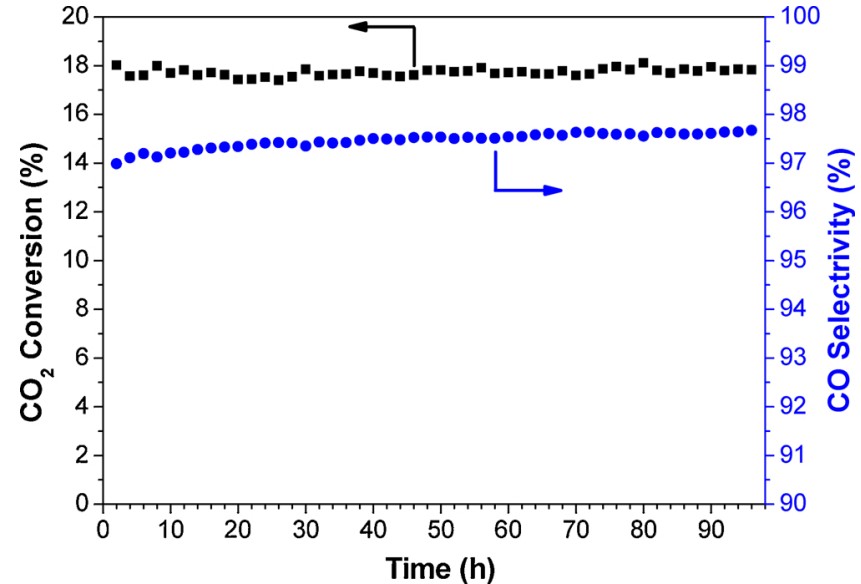

Fig. 6. Catalytic behaviour of $\mathrm{Mo}_{\mathrm{x}} \mathrm{C}-\mathrm{B}$ in RWGS at $623 \mathrm{~K}$ as a function of the time on stream: $\mathrm{CO}_{2}$ conversion and $\mathrm{CO}$ selectivity. Reaction conditions: $150 \mathrm{mg}$ catalyst, $\mathrm{CO}_{2} / \mathrm{H}_{2} / \mathrm{N}_{2}=1 / 3 / 1$, GHSV $=3000 \mathrm{~h}^{-1}, \mathrm{P}=0.1 \mathrm{MPa}$.

with those of fresh catalysts (Fig. S4), being also quite similar the calculated $\mathrm{Mo}_{\mathrm{x}} \mathrm{C}$ crystallite sizes. Besides the presence of hexagonal $\mathrm{Mo}_{2} \mathrm{C}$ and $\mathrm{Mo}^{0}$, which were already in fresh $\mathrm{Mo}_{\mathrm{x}} \mathrm{C}-\mathrm{E}, \mathrm{XRD}$ pattern of used $\mathrm{Mo}_{\mathrm{x}} \mathrm{C}$-E indicates the presence of crystalline $\mathrm{MoO}_{2}$ (Fig. S4). According with XRD results, Raman analysis of post-reaction $\mathrm{Mo}_{\mathrm{x}} \mathrm{C}-\mathrm{E}$ (Fig. S5) shows a clear increase in the intensity of the bands assigned to molybdenum oxide species with respect those of fresh $\mathrm{Mo}_{\mathrm{x}} \mathrm{C}-\mathrm{E}$ (Fig. 2). Contrarily, Raman spectra of all the other post-reaction catalysts showed bands related with molybdenum oxides with similar or lower intensity than those of the corresponding fresh catalyst.

\section{Conclusions}

New $\mathrm{Mo}_{\mathrm{x}} \mathrm{C}$ catalysts were prepared using sol-gel routes and different easy to handle Mo ad C precursors, avoiding additional $\mathrm{CH}_{4} / \mathrm{H}_{2}$ carburization treatments. $\mathrm{Mo}_{\mathrm{x}} \mathrm{C}$ catalysts were active and selective for the RWGS reaction using $\mathrm{CO}_{2} / \mathrm{H}_{2}=1 / 3$ mixture in the range $548-673 \mathrm{~K}$ at atmospheric pressure. The variation of different parameters in the synthesis, such as the Mo precursor and carbon source, influenced the final characteristics of the $\mathrm{Mo}_{\mathrm{x}} \mathrm{C}$ catalysts and their catalytic behaviour in RWGS.

$\mathrm{Mo}_{\mathrm{x}} \mathrm{C}-\mathrm{B}, \mathrm{Mo}_{\mathrm{x}} \mathrm{C}-\mathrm{C}, \mathrm{Mo}_{\mathrm{x}} \mathrm{C}-\mathrm{D}$ and $\mathrm{Mo}_{\mathrm{x}} \mathrm{C}-\mathrm{D} 1$ were highly efficient and stable for the $\mathrm{CO}$ production under the reaction conditions used. $\mathrm{Mo}_{\mathrm{x}} \mathrm{C}$ $\mathrm{B}$ which had hexagonal and cubic $\mathrm{Mo}_{2} \mathrm{C}$ and $\mathrm{MoC}$ phases showed the best catalytic performance. A CO yield of $41.8 \mathrm{~mol} \mathrm{CO} \mathrm{kg}_{\text {cat }}^{-1} \mathrm{~h}^{-1}$ was obtained over $\mathrm{Mo}_{\mathrm{x}} \mathrm{C}-\mathrm{B}$ at $673 \mathrm{~K}$ with $98.5 \%$ selectivity to $\mathrm{CO}$. A value of $\mathrm{E}_{\mathrm{a}}$ for $\mathrm{CO}$ production of $37.8 \pm 2.4 \mathrm{~kJ} \mathrm{~mol}^{-1}$ was calculated for $\mathrm{Mo}_{\mathrm{x}} \mathrm{C}-\mathrm{B}$ at $598-648 \mathrm{~K}$.

\section{Acknowledgements}

The authors thank MAT2017-87500-P project for financial support. A. P. thanks to MINECO the PhD grant BES-C-2015-074574. X. L. thanks the China Scholarship Council and the University of Barcelona (IN2UB) for her PhD grants. DJ. C.M. is grateful to the European Commission for the scholarship funded within the Erasmus + KA1 Program, ref. 20151975/001-001- EMJMD ChIR.

\section{Appendix A. Supplementary data}

Supplementary material related to this article can be found, in the online version, at doi:https://doi.org/10.1016/j.cattod.2019.11.011.

\section{References}

[1] G. Centi, S. Perathoner, Catal. Today 148 (2009) 191-205.

[2] N. Homs, J. Toyir, P. Ramírez de la Piscina, Catalytic processes for activation of $\mathrm{CO}_{2}$, in: S.L. Suib (Ed.), New and Future Developments in Catalysis: Activation of Carbon Dioxide, Elsevier, Amsterdam, 2013, pp. 1-26.

[3] Y.H. Choi, Y.J. Jang, H. Park, W.Y. Kim, Y.H. Lee, S.H. Choi, J.S. Lee, Appl. Catal. BEnviron 202 (2017) 605-610.

[4] C.-S. Chen, W.-H. Cheng, S.-S. Lin, Chem. Commun. (2001) 1770-1771.

[5] C.-S. Chen, W.-H. Cheng, S.-S. Lin, Appl. Catal. A-Gen. 257 (2004) 97-106.

[6] X. Su, X. Yang, B. Zhao, Y. Huang, J. Energy. Chem. 26 (2017) 854-867.

[7] M.D. Porosoff, B. Yan, J.G. Chen, Energy Environ. Sci. 9 (2016) 62-73.

[8] L.C. Wang, M.T. Khazaneh, D. Widmann, R.J. Behm, J. Catal. 302 (2013) 20-30.

[9] S.S. Kim, H.H. Lee, S.C. Hong, Appl. Catal. B-Environ. 119-120 (2012) 100-108.

[10] X. Chen, X. Su, H. Duan, B. Liang, Y. Huang, T. Zhang, Catal. Today 281 (2017) 312-318.

[11] S.T. Oyama, Introduction to the chemistry of transition metal carbides and nitrides, in: S.T. Oyama (Ed.), The Chemistry of Transition Metal Carbides and Nitrides, Springer, Cornwall, 1996, pp. 1-27.

[12] H.H. Hwu, J.G. Chen, Chem. Rev. 105 (2005) 185-212.

[13] C. Kunkel, F. Viñes, F. Illas, Energy Environ Sci. 9 (2016) 141-144.

[14] M.D. Porosoff, S. Kattel, W. Li, P. Liu, J.G. Chen, Chem. Commun. 51 (2015) 6988-6991.

[15] H. Tominaga, M. Nagai, Appl. Catal. A-Gen. 282 (2005) 5-13.

[16] J.A. Rodriguez, J. Evans, L. Feria, A.B. Vidal, P. Liu, K. Nakamura, F. Illas, J. Catal 307 (2013) 162-169.

[17] S. Posada-Pérez, P.J. Ramírez, R.A. Gutiérrez, D.J. Stacchiola, F. Viñes, P. Liu, F. Illas, J.A. Rodriguez, Catal. Sci. Technol. 6 (2016) 6766-6777.

[18] J.S. Lee, S.T. Oyama, M. Boudart, J. Catal. 106 (1987) 125-133.

[19] A. Hanif, T. Xiao, A.P.E. York, J. Sloan, M.L.H. Green, Chem. Mater. 14 (2002) 1009-1015.

[20] M. Patel, J. Subrahmanyan, Mater. Res. Bull. 43 (2008) 2036-2041.

[21] W. Xu, P.J. Ramírez, D. Stacchiola, J.L. Brito, J.A. Rodriguez, Catal. Lett. 145 (2015) 1365-1373.

[22] D. Zeng, M.J. Hampden-Smith, Chem. Mater. 4 (1992) 968-970.

[23] C. Giordano, C. Erpen, W. Yao, M. Antonietti, Nano Lett. 8 (2008) 4659-4663.

[24] A.M. Stux, C. Laberty-Robert, K.E. Swider-Lyons, J. Solid State Chem. 181 (2008) 2741-2747.

[25] L. Zhao, K. Fang, D. Jiang, D. Li, Y. Sun, Catal. Today 158 (2010) 490-495.

[26] G. Vitale, H. Guzmán, M.L. Frauwallner, C.E. Scott, P. Pereira-Almao, Catal. Today 250 (2015) 123-133.

[27] X. Liu, C.R. Kunkel, P. Ramírez de la Piscina, N. Homs, F. Viñes, F. Illas, ACS Catal. 7 (2017) 4323-4335.

[28] P. Delporte, F. Meunier, C. Pham-Huu, Ph. Vennegues, M.J. Ledoux, J. Guille, Catal. Today 23 (1995) 251-267.

[29] Ch. Bouchy, C. Pham-Huu, B. Heinrich, Ch. Chaumont, M.J. Ledoux, J. Catal. 190 (2000) 92-103.

[30] M. Dieterle, G. Mestl, Phys. Chem. Chem. Phys. 4 (2002) 822-826.

[31] M. Dieterle, G. Weinberg, G. Mestl, Phys. Chem. Chem. Phys. 4 (2002) 812-821.

[32] J.V. Silveira, J.A. Batista, G.D. Saraiva, J. Mendes Filho, A.G. Souza Filho, S. Hu, X. Wang, Vib. Spectrosc. 54 (2010) 179-183.

[33] M. Camacho-López, L. Escobar-Alarcón, M. Picquart, R. Arroyo, G. Córdoba, E. Haro-Poniatowski, Opt. Mater. 33 (2011) 480-484.

[34] M.-L. Frauwallner, F. López-Linares, J. Lara-Romero, C.E. Scott, V. Ali, E. Hernández, P. Pereira-Almao, Appl. Catal. A Gen. 394 (2011) 62-70.

[35] T.-C. Xiao, A. Hanif, A.P. York, Y. Nishizaka, M.L. Green, Phys. Chem. Chem. Phys. 4 (2002) 4549-4554.

[36] W. Wu, Z. Wu, C. Liang, P. Ying, Z. Feng, C. Li, Phys. Chem. Chem. Phys. 6 (2004) 5603-5608.

[37] G. Wang, J.A. Schaidle, M.B. Katz, Y. Li, X. Pan, L.T. Thompson, J. Catal. 304 (2013) 92-99.

[38] P. Arnoldy, J.C.M. De Jonge, J.A. Moulijn, J. Phys. Chem. 89 (1985) 4517-4526.

[39] Q. Gao, X. Zhao, Y. Xiao, D. Zhao, M. Cao, Nanoscale 6 (2014) 6151-6157.

[40] Y. Zhu, S. Wang, Y. Zhong, R. Cai, L. Li, Z. Shao, J. Power Sources 307 (2016) $552-560$.

[41] Y. Sun, X. Hu, W. Luo, Y. Huang, J. Mater. Chem. 22 (2012) 425-431.

[42] R. Li, S. Wang, W. Wang, M. Cao, Phys. Chem. Chem. Phys. 17 (2015) 24803-24809.

[43] M.D. Porosoff, X. Yang, J.A. Boscoboinik, J.G. Chen, Angew. Chem. 126 (2014) 6823-6827.

[44] K. Oshikawa, M. Nagai, S. Omi, J. Phys. Chem. B 105 (2001) 9124-9131.

[45] M. Chen, J. Liu, W. Zhou, J. Lin, Z. Shen, Sci. Rep. 5 (2015) 10389-10399.

[46] X. Liu, P. Ramírez de la Piscina, J. Toyir, N. Homs, Catal. Today 296 (2017) 181-186

[47] C. Álvarez Galván, J. Schumann, M. Behrens, J.L.G. Fierro, R. Schlögl, E. Frei, Appl. Catal. B: Environ. 195 (2016) 104-111.

[48] K.-H. Ernst, Ch.T. Campbell, G. Moretti, J. Catal. 134 (1992) 66-74.

[49] M.S. Spencer, Catal. Lett. 32 (1995) 9-13.

[50] B. Liang, H. Duan, X. Su, X. Chen, Y. Huang, X. Chen, J.J. Delgado, T. Zhang, Catal. Today 281 (2017) 319-326.

[51] J.L. Santos, L.F. Bobadilla, M.A. Centeno, J.A. Odriozola, J. Carbon Res. 4 (2018) $47-62$. 